\title{
Reading the Bible with Islam in Mind Ida Glaser
}

Unless the world has changed beyond recognition, everyone reading this article will have seen something frightening that is referred to as 'Islamic' in this week's news media. Most readers will also have spoken with Muslims this week, and some will have Muslims in their family or be or have been Muslims themselves. What difference, I wonder, does this make to your study of the Bible? What difference does it make to the sermons that you will be preaching or hearing next Sunday?

This article aims to give you a taste of what difference it could (and, perhaps, should) make, by exploring the questions raised by an Islamic context for the reading of particular passages of the Bible.

\section{Every passage is relevant}

If the whole Bible speaks into any context, then the whole Bible can be put into conversation with news about matters 'Islamic' and with Muslims and their beliefs. To demonstrate this point, I have simply chosen the ASB lectionary readings for the day on which I did the choosing: Isaiah 40:27-41:7, Hosea 11:1-11, Matthew 11:1-21 and Revelation 20. For the first three, we will look briefly at their relevance 'in conversation with' the Qur'an. For the last, we will look more systematically at the factors to be taken into account in 'reading the Bible with Islam in mind.'

In terms of genre, Isaiah and Hosea are prophets, and prophecy is the central act of God in Islamic sacred history. Isaiah and Hosea are not mentioned in the Qur'an, ${ }^{1}$ but their books are more in line with Islamic views of prophethood than are the biblical accounts of characters like Noah, Abraham, Lot, and Joseph, who are paradigm prophets in the Qur'an. Matthew is a gospel, and the injil (gospel) is mentioned in the Qur'an as something given by God to the prophet Jesus, as the taurat (torah) was given to Moses and the zabur (psalms) to David. There is immediate interest here for both the Muslim reader and the Christian reader in Islamic context: on the one hand, Jesus is a fascinating character in the Qur'an, about whom many Muslims would like to know more, and the Qur'an is very positive about His book; but, on the other hand, the New Testament gospels are certainly not a single book given to Jesus by God. Revelation is apocalyptic, and has some parallels with the imagery in the extensive qur'anic material on the Last Day.

In terms of content, our passages offer rich resources for Christians relating to Muslims, and for Muslims who want to understand the Gospel.

\footnotetext{
${ }^{1}$ Surah 17: 4 is thought to refer to a prophecy of Isaiah.
} 
Isaiah 40:27-41:7 contains themes that affirm qur'anic themes relating to the oneness of God: His omnipotence (40:22-24), His incomparability (40:25), His power (40:26), His knowledge (40:27), His creation (40:28), His strength (40:28), His provision for believers (40:29-31), His judgement (41:1), His universal rule (41:2-3), His eternity (41:7), and the uselessness of idolatry (41:5-7). A recognition of such agreed ideas about the nature of God can help towards dealing with both Christian fears of Islam and Muslim fears about Christianity. Further, these attributes of God are just what all human beings need to hear in the midst of all the violence reported in the media. Isaiah 40:27-41:7 is, then, an excellent resource for encouraging Christians who feel weary or helpless in seeking to share the Gospel with their Muslim neighbours, and also for reassuring Muslims that their Christian neighbours are not idolators who worship three gods.

Had the lectionary included 41:8, I might have chosen the Isaiah passage as a focus for this paper. It speaks of Israel as God's chosen servant, 'the offspring of Abraham, my friend'. This verse is packed with issues for a Muslim context. The category, 'servant of God' is the highest qur'anic accolade, Abraham is seen as the builder of the Ka'abah and the father of 'the Abrahamic faiths', and 'friend of God' is both the qur'anic and the popular title for Abraham. Following as it does from a passage about 'the coastlands', the verse also raises the question of how the choice of Israel relates to God's intent for the other nations. Many Muslims find the Bible's focus on Israel scandalous, and compare what they see as the Bible's ethnic exclusivism with the universal message of the Qur'an. One of the most important questions in reading the Bible in the context of Islam is, "What was and is the purpose of Israel?'

That question takes us to Hosea 11:1-11. The book of Hosea is interesting in an Islamic context not only because of its extended critique of idolatry but also because of its scandalous sexual imagery and its even more scandalous call to a prophet to marry a prostitute. In Islamic thinking, prophets are honourable and are preserved from major sin, and there could be little that could dishonour a prophet more than this. Taking an adulterous wife back again would be unthinkable. There is an intriguing qur'anic passage (Surah 24:11-20) that is said to relate to an incident when Aishah, Muhammad's favourite wife, was left behind in on a battle field, and was accompanied back to Medina by one of the Muhammad's companions. Suspicion of sexual impropriety arose, and Muhammad distanced himself from her for a while and was advised to repudiate her. Their relationship was only resumed on receipt of this verse. Whatever he might have believed or wanted, it would have been scandalous for him to take her back without divine intervention. ${ }^{2}$

\footnotetext{
${ }^{2}$ The story is told in Ibn Ishaq ( $8^{\text {th }}$ century) Sirat Rasul Allah, available in translation in Guillaume, A. (1955). The Life of Muhamamad. Oxford: Oxford University Press, pp.493-499. Together with Surah 24:13 and verses 1-10 of the same surah, it informs Islamic law on judging sexual misconduct.
} 
Hosea 11 is about God's even more scandalous taking back of adulterous Israel. The Qur'an agrees with the Bible that God favoured Israel above other nations, in that He sent her prophets and gave her a land and had a covenant with her (Surah 5:20-21). Israel's covenant is essentially the Mosaic covenant, and the Qur'an sees it - and other covenants - primarily in terms of the people acknowledging God's lordship and agreeing to His requirements. God's part is the gracious revelation of the requirements and the promise of reward or punishment that follows keeping or breaking them. The Qur'an also agrees with the Bible that Israel repeatedly broke her part in the covenant - it has several passages about her rebellions (e.g. Surah 2:53-74; 4:154-161; 7:138-141; 7:160-162), and hints at the sin that led to the exile and to the fall of Jerusalem (Surah 17:4-8). This is where the Bible and the Qur'an part company - where Hosea 11 pictures God's agony over the necessity of judgement and His commitment to somehow continue His relationship with Israel, the Qur'an implies that Israel's sin resulted in the loss of God's favour:

They (the Jews) broke their pledge, so We distanced them (from Us) and hardened their hearts. (Surah 5:13)

The Jews and the Christians say, 'We are the children of God and His beloved ones.' Say, 'Then why does He punish you for your sins? (Surah 5:18)

Most poignantly, we see this in the making of the covenant with Abraham:

When Abraham's Lord tested him with certain commandments, which he fulfilled, He said, 'I will make you a leader of people.' Abraham asked, 'And will You make leaders from my descendants too?' God answered, 'My pledge (covenant) does not hold for those who do evil.' (Surah 2:124)

This takes us to the question of the love of God: what do we mean by saying that God loves? Hosea shows us God's love for His sinful people: the Qur'an is clear that God loves those who do good and does not love those who do evil. For example, in Surah 2:

God does not love those who overstep the limits (190). God loves those who do good (195). God loves those who turn to Him, and He loves those who keep themselves clean. (222) He does not love the ungrateful sinner (276).

There is an important difference here that indicates that the word 'love' (as it translates various words in biblical Hebrew and Greek and in qur'anic Arabic) has different meanings within biblical and qur'anic thought. The question of 'love' has become important in current Christian-Muslim dialogue, following the publication in 2007 of 'A Common Word', an open letter to Christian leaders from Muslim leaders. ' 'A Common Word' is a call for Christians to

\footnotetext{
${ }^{3}$ See http://www.acommonword.com/. The website includes many responses to 'A Common Word' as well as the letter itself.
} 
agree with Muslims that the commandments to love God and neighbour are the central planks of both faiths and therefore offer a firm foundation for Muslim-Christian relations. The letter has generated a huge amount of discussion. Hosea 11 is an excellent place for Christians to explore what they mean by 'love', and for Muslims to consider what the Bible means by God's love for us and our love for Him.

The themes of covenant, of God's requirements, of the nature of love, of Jewish rebellion and of God's servant are all picked up in Matthew 12:1-21. All make this passage relevant in Islamic contexts. However, there are additional points of interest as we move into the New Testament.

The question of the Sabbath and Sabbath breaking is raised by the Qur'an. Islam has no Sabbath, but the Qur'an recognises that the Jews were given laws about the Sabbath, and chastises them for breaking it:

Remember when We took your pledge, and made the mountain tower high above you, and said, 'Hold fast to what We have given you and bear its contents in mind, so that you may be conscious of God.' Even after that you turned away. Had it not been for God's favour and mercy on you, you would certainly have been lost. You know about those of you who broke the Sabbath, and so We said to them, 'Be like apes! Be outcasts!' We made this an example to those people who were there at the time and to those who came after them, and a lesson to all who are mindful of God. (Surah 2:63-66. See also Surah 7:163-167)

In the Qur'an, the Sabbath is one of the laws given to the Jews but not required from other peoples. Matthew 12 uses the Sabbath to explore the whole question of the place of the law which is, of course, a key question in the context of Islam. Matthew 12 is an excellent place to compare Muslim and Christian views of law: What is its purpose? Is it necessary or contingent? How do we decide between apparently conflicting commandments? And between following the details of a law and carrying out its intention? What is the place of the history of the interpretation and practice of the law by the believing community? Current Muslim discussions about such issues in relation to shari'ah rulings can help Christians to understand the concerns of the Pharisees in Matthew 12, and therefore better to understand the impact of Jesus' teaching and actions. For example, Islamic discussions about exemptions from fasting during Ramadan weigh danger to the health of the faster or to other people against the clear command to fast. Matthew 12:1-8 could make a useful contribution to those discussions, and the discussions could make a helpful introduction to a sermon on Matthew 12.

Verses 9-14 continue and intensify the theme of law-keeping, culminating in the Pharisees' determination to destroy Jesus. This is of interest because it is in agreement with the qur'anic view that the Jews wanted to destroy their Messiah (Surah 4:157), but also because 
it raises questions about how people who are focussed on law-keeping react to people who threaten their laws. Is there something here that can help Christians to understand why, in some circumstances, Muslims see them as a threat to their communities? And is there something that can help them to understand why some Christians see Muslims as a threat?

It is particularly interesting that the Pharisees' enmity is sparked here by a healing. One of the unique things about Jesus in the Qur'an is that He is given healing miracles by God. He even heals lepers and raises the dead (Surah 3:49; 5:110). However, the Qur'an gives no details, and does not discuss the purpose of the miracles. This passage is, therefore, likely to interest Muslims who are curious about what healings Jesus did and why.

The lectionary reading does not end there. We are in the week leading up to Advent Sunday, and the lectionary is moving us towards the comings of Jesus. So the reading is about how Jesus comes to fulfil the law, to be the servant spoken of in Isaiah, and to carry out what is in God's heart in Hosea. That is, He is God's Messiah. 'Messiah' is a frequent title of Jesus in the Qur'an, and most Muslims know Him as 'isa al-masih (Jesus the Messiah). However, the Qur'an gives no indication of what this title means, apart from linking it to the Jews - Jesus was the Jews' Messiah (Surah 4:156-7). There is a tradition of discussion about the meaning of 'messiah' amongst qur'anic commentators, ${ }^{4}$ but most Muslims today simply think of it as a name. Matthew 12:15-21 opens up the title, using another qur'anic title for Jesus: servant ('abd) (Surah 4:172; 19:30). It goes on to speak of God's Spirit being on Jesus: again, this is echoed in the Qur'an:

We gave Jesus, son of Mary, clear signs and strengthened him with the Holy Spirit. (Surah 2: 87)

The Qur'an goes further, and says that Jesus is 'a spirit from God' (4:171), and the most popular title for Jesus amongst many Muslims is ruhullah - 'Spirit of God', which parallels Abraham as khalilullah - 'Friend of God'.

Matthew 12:15-21, then, is an excellent place for beginning to think about how the Gospels explain the meaning of these qur'anic ideas about Jesus. But it takes us still further. A common Muslim idea is that Jesus was a prophet for the Jews, and that it was Paul who then took the Gospel and changed it and took it to the Gentiles. Matthew's quotation from Isaiah makes it clear that the purpose of Jesus was to take God's hope to the Gentiles. It can also take us back to Isaiah, to the universal vision of that Old Testament prophet, and to the vexed question of the purpose of Israel mentioned above.

\footnotetext{
${ }^{4}$ A survey of the discussions can be found in Robinson, N. (2014). Jesus. In The Encyclopaedia of the Qur'ān., Georgetown University Press: Brill Online. Accessed via Oxford University libraries <http://referenceworks.brillonline.com/entries/encyclopaedia-of-the-quran/jesus-EQCOM_00099> on 04 December 2014.
} 
I hope that, by now, the reader is beginning to see the point of purposely asking how biblical passages relate to Islamic thinking. We will now turn to a more systematic approach to 'reading the Bible with Islam in mind', illustrating the system through the fourth lectionary passage, Revelation 20.

\section{What is involved in reading the Bible with Islam in mind?}

Using a simple hermeneutical model, any reading of the Bible will take into account:

- The world behind the text: that is, the world of the biblical authors and their first readers;

- The world of the text: that is, the text itself, and its place within the whole Bible;

- The world in front of the text: that is, the world in which the readers live today.

The first two 'worlds' do not change according to who is reading the Bible. Any valid interpretation needs to be faithful to what the text actually says, to how it says it, to its place in the Bible and, as far as is possible, to the world in which it was first written. However, applying this interpretation to the world of the reader will involve somehow putting the text into conversation with the world in front of the text. This 'conversation' both communicates the Bible into the world and takes the questions raised by the world to the Bible: an intrinsic part of the conversation is the readers' faithful living in obedience to the text and the Holy Spirit as well as the readers' faithful speaking of the message. In Islamic contexts, the 'world in front of the text' can be substantially different from the world assumed by most biblical scholarship.

The world of Islam is, of course, very varied, but there are several elements in common to most Islamic contexts. For a thorough reading, each element will be put 'into conversation with' the Bible. Revelation 20 will then be used as an example in each case.

\section{Element 1: The Qur'an}

The Qur'an has a version of many biblical stories, of what Jews and Christians received as revelation from God, and of what they had done in response and were doing at the time of Muhammad. This is what makes Islamic contexts different in kind from all other contexts. Jewish and Mormon contexts have their own authoritative additions to the Bible, which imply different interpretations of the Bible, and these produce their own challenges for Christian readers. Hindu, Buddhist and Sikh contexts have their own stories about the nature of the world, and have scriptures that are quite different from the Bible; and these, too, produce their own challenges for Christian Bible readers. The challenge of Islam is that it has a scripture that tells a different version of the biblical story.

Revelation 20 can be read alongside the extensive qur'anic material on the last days, the resurrection of the dead and the final judgement - all central foundations of any Muslim worldview. Particular points of interest include: 
The history and end of Satan. Satan and 'satans' appear in numerous places in the Qur'an as the enemies of human beings. Their major role is to lead people astray from the worship of the One God. The origin of the qur'anic Satan is also described in several places (2:34; $7: 11-18 ; 15: 30-42 ; 17: 61-65 ; 18: 50 ; 20: 116 ; 38: 71-85)$. The story reflects the Christian story of Satan as a rebellious angel who refused to bow to Adam, ${ }^{5}$ and is usually told alongside the story of Adam. In Surahs 2, 7 and 20, it is a precursor to the temptation and disobedience of Adam, which led to Adam's repentance and to Satan and the humans together being sent down from paradise to earth, with Satan as the sworn enemy of humankind. The frequency of mention of the story and of Satan's subsequent activity is an indication of its importance. The Qur'an, however, has little to say about the ultimate fate of Satan. A repeated theme in the narratives about his origin is the idea that he has 'respite' until the Day of Judgement:

We created you, We gave you shape, and then We said to the angels, 'Bow down before Adam,' and they did. But not Iblis: he was not one of those who bowed down. God said, 'What prevented you from bowing down as I commanded you?' and he said, 'I am better than him: You created me from fire and him from clay.' God said, 'Get down from here! This is no place for your arrogance. Get out! You are contemptible!' but Iblis said, 'Give me respite until the Day people are raised from the dead,' and God replied, 'You have respite.' And then Iblis said, 'Because You have put me in the wrong, I will lie in wait for them all on Your straight path: I will come at them-from their front and their back, from their right and their left-and You will find that most of them are ungrateful.' God said, 'Get out! You are disgraced and banished! I swear I shall fill Hell with you and all who follow you! (7:11-18. See also 15:34-38; 38:74-81).

Satan and all who follow him will eventually be thrown into 'Hell' (see Surah 26:94 for this graphic imagery). The Arabic word is jahannam, cognate with gehenna. Almost synonymous with jahannam in the Qur'an is an-nār, 'The Fire'. Revelation 20, it seems, is describing at the end of the world something of which the Qur'an has hints in its descriptions of the beginning of the world.

A further point of interest is that Revelation 20:2 refers to a single character as 'the Devil and Satan'. The reader may have noticed that the Satan character in the above passage from Surah 7 is called 'Iblis'. This is common in the qur'anic references to the Adam stories. The word Iblis is thought to be derived from the word diabolos. Some Muslims are interested in the two names of Satan, so Revelation 20:2 can be a starting point for discussion.

Gog and Magog are mentioned twice in the Qur'an (Arabic yājūj and mājūjj). In Surah 21:9497, they 'are let loose and swarm swiftly from every highland' as a precursor to the Last Judgement. In 18:94-98, they appear in the story of Dhu I-Qarnayn, who is usually identified

\footnotetext{
${ }^{5}$ For example in The Life of Adam and Eve, probably $4^{\text {th }}$ century.
} 
as Alexander the Great. Alexander builds a barrier to protect people from Gog and Magog until God breaks it down at the end of history. ${ }^{6}$ Putting these two passages together, we see that Gog and Magog are dangerous peoples who are being restrained. Their release and the consequences of that release will be one of the signs that the Last Judgement is imminent.

The Books. As has been mentioned, the Qur'an is replete with references to the Last Judgement. The dead will rise, it tells us, and will then be judged, some going to Hell and some to Paradise. One of the ways in which the judgement is reached is through written records of peoples' deeds that are kept by their recording angels:

When the sky is ripped apart, obeying its Lord as it rightly must, when the earth is levelled out, casts out its contents, and becomes empty, obeying its Lord as it rightly must, you humans, toiling laboriously towards your Lord, will meet Him: whoever is given his record in his right hand will have an easy reckoning and return to his people well pleased, but whoever is given his record from behind his back will cry out for destruction-he will burn in the blazing Fire. (Surah 84: 112. See also $50: 17-24 ; 83: 1-21 ; 45: 28-30$ (this refers to nations rather than to individuals); 69:13-31; 81:10).

The Qur'an has the books in which peoples' deeds are written, but not the 'other book' - the book of life (Rev. 20:12-15).

\section{Element 2: The Islamic sources that complement and build on the Qur'an}

These include the Hadith, Sira (life of Muhammad), and the classical commentaries and law books. Different groups accept different sources as authoritative, but the general pattern of interpreting the Qur'an through the lenses of the classics is common. Since the Qur'an has so much on Jews and Christians, and since much of classical Islam was developed in situations where Muslims were ruling over Jews and Christians, it is not surprising that these sources all contain material relating not only to Jewish and Christian beliefs and practices but also to the Bible. The sources are of much more than historical significance, not only because they represent the foundations of current Islamic thought and practice, but also because precedence is of much more importance in Islamic than in Christian thinking.

Particularly relevant to our reading of Revelation 20 is the tradition of interpretation of the passages about Satan, Gog and Magog and the Last Judgement mentioned above, and the

\footnotetext{
${ }^{6}$ The association of Alexander with Gog and Magog is also found in Jewish and Christian writings. For references, and for further details of Muslim traditions about Gog and Magog, see Lewinstein, K. (2014). Gog and Magog. In The Encyclopaedia of the Qur'ān. Georgetown University Press: Brill Online. Accessed via Oxford University libraries <http://referenceworks.brillonline.com/entries/encyclopaedia-of-the-quran/gog-andmagog-EQSIM_00172> on 29 November 2014.
} 
range of apocalyptic thinking about the end of the world that has arisen from this. ${ }^{7}$ The early material grew out of a situation in which Byzantium was seen as an important challenge to the Muslim empires, so that the conquest of Constantinople was an important goal. Typically, the apocalyptic expects the conquest of Constantinople; the appearance of Dajjal (usually translated 'Antichrist) in the east, leading an army and tempting Muslims to abandon their faith; and then the return of Jesus (and/or, in some traditions, of the Mahdi). Jesus will, among other things, defeat Dajjal in Jerusalem and convert Christians to Islam. Gog and Magog play important parts in these stories, as a monstrous horde unleashed after the appearance of Jesus, and defeated through Jesus' prayers. There are also many Hadith and much discussion about the resurrection of the dead and the details of the judgement.

\section{Element 3: The long history of Muslim views of Christians and of Jews}

The long history of Muslims views of Christians and Jews naturally includes views of their Scriptures. Whilst the Qur'an itself is very positive about the Bible, there is a notable history of Islamic polemic against the Bible as a whole, and against the Gospels and Paul in particular. ${ }^{8}$ However, there is also a history of uses of the Bible, either to explain qur'anic references or to claim predictions about the coming of Muhammad. Very occasionally, one finds a scholar who uses the Bible in interpreting the Qur'an, or who defends the Bible against critical scholarship, realising that, insofar as the Qur'an affirms the Bible and agrees with the Bible's stories, if the Bible is unhistorical, then so is the Qur'an. ${ }^{9}$

The older Islamic texts do not, as far as I know, deal with Revelation. However, some recent Muslim apocalyptic writings use it extensively, as they ask how current events in the Middle East might relate to the signs of the last days. 'The saints', it is contended by some, are the Muslims, because they are the true worshippers of God (Rev. 15:1-4), they have marks on their foreheads as Muslims do from frequent prayer (Rev. 7:3), and they bow down in prayer (Rev. 11:16). The new song of Rev. 19:1-7 is the shahada (Islamic creed), the 'faithful and true' one of Rev. 19:11-16 is the Mahdi, and the new Jerusalem of Rev. 21 is Mecca. This is in the context of seeing the Jews as representing the Dajjal, with the Christians (especially the USA) as their allies. In his introduction to his survey of contemporary Muslim apocalyptic literature Cook comments: 'The materials surveyed here are graphically anti-Semitic and virulently anti-Western, very frequently exhibiting a blood lust and level of hatred stunning to the unprepared.' 10

\footnotetext{
${ }^{7}$ Cook, D. (2005). Contemporary Muslim Apocalyptic Literature. Syracuse: Syracuse University Press, contains a helpful summary of classical material as well as a survey of how this has developed into thinking about current events.

${ }^{8}$ For accessible explorations of a variey of views, see The Centre for Muslim-Christian Studies Research Briefing no.2 (2014), Muslim Views of the Bible: past and present. ISBN 2056-4996 print. Online at http://cmcsoxford.org.uk/resources/research-briefings/

${ }^{9}$ Such as Khan, S.A. (1862). The Mohommedan Commentary on the Holy Bible, Ghazeepore or Mir, M. (2008). Understanding the Islamic Scripture: A Study of Selected Passages from the Qur'an. New York: Pearson Longman.

${ }^{10}$ Cook, D. (2005). Contemporary Muslim Apocalyptic Literature. Syracuse: Syracuse University Press, p.5.
} 
Apocalytic literature is by nature graphic and over-stated, and such writings might not represent a majority view. However, they express a strand of current Muslim thought that cannot be ignored.

\section{Element 4: The long history of Christian-Muslim relations}

One element of this relationship is Christian use of the Bible in thinking about Islam and about Muslims. Apocalyptic writings have long been used to try to make sense of periods of history when Christians have been conquered by Muslims. Particularly popular have been the books of Daniel and Revelation, and the identification of Islam with the fourth beast of Daniel 7.

Many of these Christian writings were influenced by the seventh century The Apocalypse of Pseudomethodius, which uses Genesis, Daniel and Matthew 24 as its main basis for describing history as series of kingdoms which arise in a series of millennia. The 'sons of Ishmael' (clearly the Muslim conquerors) rise during the $7^{\text {th }}$ millennium, bringing God's judgement on the Christian kingdom, with terrible suffering and sin, and many Christians fall away. This conquest is necessary so that the 'Son of Perdition' who heralds the Last Days can be revealed. Eventually, a messianic figure called 'The King of the Greeks' will overcome the Ishmaelites, ushering in a period of unprecedented peace on earth. This will be followed by the unleashing of imprisoned hordes, the rise of the 'Son of Perdition'/Antichrist, and a final conquest by the 'King of the Greeks' and the sign of the cross. ${ }^{11}$

There are obvious resonances with Revelation here, including the period of peace, which might refer to the millennium of Revelation 20. We can also see parallels with the Islamic apocalyptic described above: it seems that the Muslims mirrored the thinking of Christians (and of Jews), but they expected the Muslims and not the Christians to win in the end. The current Islamic apocalyptic also mirrors current Christian thinking. There are Muslims who express their fear and anger by describing the 'Christian' West as conspiring with the Jews to bring about the end of Islam, with the Jews as the Antichrist, and the Christians/the West the Antichrist's supporters. This mirrors Christians who see Muslim nations as fulfilling the prophecies about last time warfare, with Islam as the Antichrist and the Middle East as the theatre for the fulfilment of prophecy about the Last Days. Such ideas are often linked to particular interpretations of the millennium of Revelation $20 .{ }^{12}$ Whilst authors state their

\footnotetext{
${ }^{11}$ See Alexander, P.J. (1985). The Byzantine Apocalyptic Tradition. Berkley: University of California Press, pp.3651, for an English translation of the Syrian text. Hoyland, R. (1997). Seeing Islam as others saw it: A survey and evaluation of Christian, Jewish and Zoroastrian writing on early Islam. Princeton: The Darwin Press, chapter 8 gives a summary of other apocalyptic material.

12 Popular books include Smith, J. (2011). Islam, the Cloak of the Antichrist. USA: Wine Press and Richardson, J. (2009). The Islamic Antichrist. Los Angeles: WND Books. Kyle, R.G. (2012). Apocalyptic Fever: End-Time Prophecies in Modern America. Eugene: Cascade Books, indicates the influence of premillennialism on the end times discourse in the USA. Chapter 7 traces the rise of interpretations that focus on Islam, and pp.173-175 summarise several views of Islam as the vehicle of the Antichrist.
} 
intention of loving Muslims, we might ask how far all this might breed amongst Christians something of the 'blood lust and hatred' observed in the Muslim writings.

\section{Element 4: The variety of Muslim cultures}

Cultures affect the ways in which people understand the Bible. Muslim cultures vary, but they have aspects in common that reflect aspects of Islam. For example, family structures are affected by Islamic law, and concerns about honour and shame are often undergirded by Islamic concerns. Muslim cultures are often closer to the cultures in the 'world behind the text' than are western cultures, so may provide good contexts for opening up the Bible. ${ }^{13}$

Most Muslim contexts have a much greater awareness of Satan than do western Christian contexts. In addition, there are not only the 'satans' but also the jinn - spiritual beings that can be either good or bad. Many cultural practices are the results of such beliefs - for example, the first cry of a baby may be seen as a sign that Satan has touched it, and people have various practices to protect mother and child from evil influences. These may include the use of amulets, and not leaving the baby alone for the first 40 days of its life. ${ }^{14}$ The control and the conquest of Satan as described in Revelation 20 is, therefore, very good news in Muslim contexts.

\section{Element 5: Specific issues}

Islamic contexts raise questions and issues that can be taken to the Bible. There are theological issues, as Muslims question basic Christian beliefs; there are practical issues, as halal food appears on our menus and Muslims ask us why we eat pork, how we decide what to wear, or how we organise our families; and there are social and legal and political issues galore.

The current issue that jumps out of Revelation 20 is that of martyrdom. Christians were being beheaded 'for the testimony of Jesus and for the Word of God' (20:4). Our news has been full of beheadings by the self-designated 'Islamic State', and of Christians suffering for their faith. In various places in today's world, it is all too possible that Christians will quite literally be beheaded for refusing to deny Christ, and that this will be done in the name of Islam. At the same time, there is huge disagreement amongst Muslims about the nature of martyrdom, as some make 'suicide' attacks on Christian, Jewish and Western targets.

\section{So how shall we read Revelation 20?}

First, we read Revelation 20 as speaking to the fears and concerns of Christians under pressure. The beheaded Christians in 20:4 are a key to the vision, which was seen by someone who shared their suffering 'for the Word of God and for the testimony of Jesus'

\footnotetext{
${ }^{13}$ Bailey, K.E. (2008). Jesus Through Middle Eastern Eyes: cultural studies in the Gospels. London: SPCK, gives a taste of the insights that can be gained by taking the Middle eastern cultural context into account.

${ }^{14}$ Other practices surrounding births are described in Musk, B. (1989). The Unseen Face of Islam. Eastbourne: Monarch, pp.132-134.
} 
(Rev. 1:9). Those Christians are an important part of the kingdom of Christ, and of the new heavens and earth to come.

Second, the history of ideas about the role of Islam in the end times should alert us to the possibility that current speculations might be no more accurate than those of the seventh century. Perhaps more importantly, they should make us ask, 'Why do these interpretations arise at particular times in history?' They can help us to see the fears and concerns that drive our interpretations, and to focus on the intent of the passages. Speculations about identifying Islamic nations with Gog and Magog may be interesting, and it could be that events in the Middle East are heralding the last Days. It might also be helpful for Christians to learn about how pre-milliennialist dispensational thinking can lead to hostility towards Muslims. However, given the New Testament focus on salvation, the intention of the chapter cannot be to make its readers afraid or angry, or to pitch them in battle against people they think might be Gog and Magog. The intention of Revelation 20 is not to foster fear but to inspire faith.

Third, reflection on Islamic views of the end times and of Revelation can help us to see ourselves as some Muslims see us, and to understand something of the human dynamics of current tensions. This can both challenge our own attitudes and help us to empathise with Muslims as human beings. All human beings are caught up in the last battles.

Fourth, Revelation 20 can help us to ask, 'What really matters?' In addition to the reign of the martyrs, we have the reign of Christ, the defeat of Satan and the final judgement. The secular world is not interested in Satan or in Judgement: conversation with Muslims can alert us to these realities, and make the insights of Revelation more urgent. There is a real battle; and what happens to us at the final judgement is really the only thing that matters. It is the One on the throne who will deal will all evil, whether in Satan and his hordes, in the principalities and powers of this world, in the enemies of the Gospel, or in us. We are called to faithfulness and to making sure that our names are in the Book of Life.

Fifth, there is Good News for Muslims here. Many Muslims are struggling with satanic temptations and are trying to pacify malevolent spirits. The Good News is that all these evil powers are subject to the reign of Christ - now, as well as at the end of time. All faithful Muslims work to make sure that their record books will contain as much good and as little bad as possible when they are opened at the final judgement; but they do not know of 'the other book' - the Book of Life, where their names can be written because of what Jesus has done for them. The 'other book' is Good News for them. The comparison with Islam can help Christians to be amazed again at the Gospel, to be motivated to share that Gospel, and to be reminded that, in addition to the 'other book', the books of their own good and bad deeds will be opened. 
Revelation 20 will take us on to the new heavens and the new earth of Revelation 21 and 22: to the triumphant 'dwelling of God' amongst human beings (21:3). The coming of God to earth, the dwelling of God amongst humans, is not envisaged in Islamic thinking and is, for most Muslims, unthinkable. Above all, Revelation gives us a glimpse of the nature of God and of the Lamb that should make us bow down in worship before the throne right now, and not wait for the judgement day. Perhaps we should be challenged by the Muslim author who says that the bowing down of the elders in Rev. 11:16 identifies them as Muslims. Should not Christians fall on their faces before the God who comes and who provides 'another book'?

\section{In conclusion: Why read the Bible with Islam in mind?}

We read the Bible with Islam in mind quite simply because we have no choice but to read the Bible in the context of the world in which we live, and Islam is part of that world. The question is not so much whether we read in the context of Islam, but whether we do so deliberately and appropriately. A church in Bradford or in London is doing its biblical study with Muslims next door or down the street; but does that study equip people to relate to Muslims, to understand Islam, to explain their faith to Muslims, and to help Muslims to see Jesus as Lord?

The matter has become urgent for at least three reasons: ${ }^{15}$

First, an increasing number of people coming to Christ from Muslim backgrounds are reading the Bible with Islam in their minds. People from Christian background who are discipling them and advising them have to discern appropriate Bible teaching, and to help them to put the Bible into conversation with their cultures and their contexts. This has generated a great deal of controversy, centred around the idea of 'insider movements'. ${ }^{16}$ There will be an ongoing need for serious biblical study that addresses all the issues raised, just as there is a need for ongoing serious biblical study that addresses all the issues raised by 'post-modern' western contexts.

Second, there are questions about appropriate Bible translation in Islamic contexts. Most controversial have been questions surrounding the translation of 'divine familial language' that is, of words translating the Greek pater and huios, which are usually translated 'Father' and 'Son'17 (the problem being that the very words can cause strong negative reactions and prevent Muslims from reading the Gospels). However, there are also questions about other words and phrases that arise in different contexts. Translation necessarily involves a degree

\footnotetext{
15 The debates surrounding these issues are helpfully presented in the October 2013 issues of The Evangelical Review of Theology, Vol 37 No 4.

${ }^{16}$ The debate is largely conducted through The St Francis Magazine, http://www.stfrancismagazine.info/

${ }^{17}$ The WEA report that responds to this controversy is available at http://www.worldea.org/images/wimg/files/2013 0429Final\%20Report\%20of\%20the\%20WEA\%20Independent\%20Bible\%20Translation\%20Review\%20Panel.pdf
} 
of interpretation, and serious biblical study that takes the context of the new language into account is essential.

Third, there are polarised discussions about the nature of Islam which cause heated controversy amongst Christians in the West, and also elsewhere in the world. The presenting questions are usually about the nature of Islam, but there are underlying issues about how we understand humanity and religion, and about how Islam, in all its variety, fits into that understanding. There are then issues about how we should respond to the various aspects of Islam that we see, and to the Christian brothers and sisters who see other aspects. We need serious biblical study as a basis for all this.

In short, the work of reading the Bible in the context of Islam is no less important than the work of reading the Bible in any other context - it is necessary to help us to think about the world, to respond to the world, to live faithfully within the world, to translate and teach the Bible, to share the Gospel and to disciple believers.

Dr Glaser is Academic Director of the Centre for Muslim-Christian Studies in Oxford. She has lived and worked amongst Muslims in Asia and in inner-city Britain, and has taught on Islam, mission and comparative religions in the UK, India, Nigeria, Jamaica and the Philippines. She has been with Crosslinks since 1992, leading their Other Faiths Team before being seconded to teaching, research and consultancy posts. She is married to David Coffey and they live in Oxford. 